\title{
HAREKETLI GRAFIKLERIN GÖSTERGEBiLIMSEL ÇÖZÜMLENMESi; INTENTION ÖRNEĞi
}

\author{
SEMIOTIC ANALYSIS of MOTION GRAPHICS; INTENTION CASE
}

\author{
Ibrahim Halil Özkirişçi*
}

\section{Öz}

Kavramsal düşüncenin görsel iletişim diline aktarılmasında grafik tasarımı, geçmişten günümüze farklı biçemlerle kendini göstermiş̧ir. Gelişen teknoloji ile değişen iletişim yöntemleri, grafik tasarımın düşünsel algoritması ve araçlarında da kendini göstermiştir. Hareketli Grafikler bu anlamda, günlük yaşantılarımııın neredeyse her anında maruz kaldığımız ve okunması gereken görsel bir dil haline gelmiştir. Göstergebilim ise yaşadığı her dönemde çevre ile anlamlı ilişkiler kurma ihtiyacı hisseden türümüz için bir algoritmalar bütünü görevi görmüştür. Anlamlandırma sürecini etkileyen medyumlar ve bilişsel seviye düşünüldüğünde, göstergebilimsel terminoloji de kendi tanımlarını ve bilgisel alışveriş sürecini yeni iletişim araçlarının karşısında yeniden anlamlandırmak durumunda kalmıştır. Bu çalışmanın amacı, hareketli grafikler dilinin göstergebilimsel anlamda çözümlenmesi ile görsel okuryazarlığın ve görsel farkındalı̆ı̆n hem tasarımcı hem de izleyici açısından artırıımasıdır. Bu bağlamda, Apple şirketinin tasarım manifestosu için yayımladığı hareketli grafik çalışması; Intention örneğinin, göstergebilimsel çözümleme yöntemi ile analizi yapılmıştır. Nitel ve betimsel bir yöntemle ilerleyen araştırmada, temel göstergebilim bileşenleri ile hareketli grafik tasarımı arasındaki ilişki irdelenip örnek çalışma üzerinden yorumlanarak sonuçlandırılmıştır.

Anahtar Kelimeler: Grafik Tasarımı, Hareketli Grafikler, Göstergebilim.

\begin{abstract}
Graphic design has shown itself in different styles from past to present in transferring conceptual thinking to visual communication language. The changing communication methods with the developing technology have also shown themselves in the intellectual algorithm and tools of graphic design. In this sense, Motion Graphics has become a visual language that we are exposed to in almost every moment of our daily lives and must be read. Semiotics, on the other hand, has served as a set of algorithms for our species, which feels the need to establish meaningful relationships with the environment in every period of its life. Considering the mediums and cognitive level that affect the signification process, semiotic terminology has also had to re-interpret its own definitions and informational exchange process against new communication tools. The aim of this study is to increase visual literacy and visual awareness in terms of both the designer and the audience by analyzing the motion graphics language in a semiotic sense. In this context, the motion graphics work published by the Apple company for the design manifest; Intention sample was analyzed by semiotic analysis method. In the research, which proceeded with a qualitative and descriptive method, the relationship between basic semiotics components and motion graphic design was examined and concluded by interpreting it through a case study.
\end{abstract}

Keywords: Graphic Design, Motion Graphics, Semiotics.

\footnotetext{
Araştırma Makalesi // Başvuru tarihi: 01.09.2021 - Kabul tarihi:20.12.2021.

*Araştırma Görevlisi, Gaziantep Üniversitesi, Güzel Sanatlar Bölümü, Grafik Bölümü, halilozkirisci@gmail.com, https://orcid.org/0000-0002-3797-0698.
} 


\section{Giriş}

Günlük hayatlarımızdaki iletişim ve öğrenme süreçlerinde görme duyumuzun \%75 ile \%90 arasında aktif olarak kullanıldığı göz önünde bulundurulduğunda (Arıkan, 2008) görsel iletişimin ve imge okuryazarlığının bizler için hayati önem taşıdığı açıktır. Görsel iletişim tasarımı ise bu alışverişinin kodlarının incelendiği ve işlendiği disiplin olarak kabul edilmektedir. Görsel iletişim tasarımı bireyin iletişim ihtiyacının olduğu her düzlemde kendini göstermektedir. Kullandığı araçları, sosyokültürel yapıya paralel, sürekli yenileyen insanoğlunun bu reaksiyonunu görsel iletişim ve tasarım araçları alanında da sürdürdüğü görülmektedir. Yaşadığımız dijital iletişim çağına ve düzlemine yönelik geliştirdiğimiz biçemlerin içinde de hareketli grafiklerin yeri gözardı edilemeyecek bir seviyeye ulaşmıştır. Ulaşılan bu seviye, beraberinde tasarımın gerçekleştirilmesi ve okunması noktalarında, görece farklı alanlarla iş birliğini gerekli kılmıştır. Her görsel iletişim aracının olduğu gibi hareketli grafiklerin de temel bileşenini imgenin kendisi oluşturur. İmgenin okunması konusunda ise kullandığımız gözlüğün göstergebilim olması hem tasarımcının, imgenin algılanma ve okunma süreci bilgisi ile farkındalığının artmasına hem de izleyicinin görsel okuryazarlığının daha nitelikli hale gelmesini sağlamaktadır. Apple şirketinin 2013 yılında yayınladığı tasarım manifestosu Intention çalışması, minimal ve yalın bir üsluba sahip olması, temel hareketli grafik bileşenlerinin dengeli kullanılması ve göstergebilimsel kavramların rahat okunabileceği bir akışa sahip olması sebebi ile tercih edilmiştir. Çalışmayı oluşturan unsurlar önce demonte edilerek göstergebilimsel bakış açısı ile tanımlanacaktır. Tanımlanan unsurların izlekteki rolleri, mekânsal varlıkları, plastik özellikleri ve diğer unsurlarla girdiği ilişkiler ile nasıl anlamlandığı incelenecektir.

\section{Araştırmanın Amacı ve Önemi}

Bu araştırmada, Apple şirketinin 2013'te yayımladığı tasarım manifestosu olan Intention hareketli grafik çalışmasının göstergebilimsel çözümle ile analizinin yapılması amaçlanmaktadır. Görsel iletişim anlamında yalın ve özgün bir üslubu olan çalışmanın hareketli grafik tasarımın temel bileşenleri bağlamında etkili bir dile sahip olduğu görülmektedir. Literatüre katkı sağlayacağı düşünülen bu araştırma ile hareketli grafik tasarımcısı bakış açısından göstergeler analiz edilerek tasarımcı farkındalığının artırılması amaçlanmaktadır. 


\section{Araştırmanın Yöntemi}

Araştırmaya konu olan çalışma, Peirce'ın görüntüsel gösterge, belirti ve simge olarak üçe ayırdığı semiyotik terminoloji üzerinden analiz edilecektir. Analiz, biçim, renk hareket ve tipografi gibi unsurlar üzerinden yürütülecektir. Çalışmadaki göstergelerin ilk aşamada görüntüsel bağlamda temel anlamları incelenecektir. Belirti adımında ise göstergelerin ikinci katmanına inilerek sebep sonuç ilişkileri anlamında analizleri yapılacaktır. Simge aşamasında ise evrensel kültürel kodların imgeleştirildiği sahneler yorumlanacaktır.

\section{Araştırmanın Sınırılıkları}

Araştırma için seçilen hareketli grafik çalışması Apple şirketinin 2013'te yayımladığı tasarım manifestosu Intention örneği ile sınırlıdır. Bu çalışma, teorik ve görsel anlatının birleştiği örnekler sunabilmesi sebebi ile tercih edilmiştir.

\section{Göstergebilim Üzerine}

Semiologie kelimesi ilk olarak Antik Yunan dilinde gösterge anlamına gelen semeion ve söylem, söz, kuram anlamına gelen logia kelimerinden türetilmiştir. Semeion kavramı, ilk olarak 4. yüzyılda Hipokrates ve Parmenides tarafından kanıt, belirti, semptom anlamlarındaki tekmerion kelimesinin anlatısına paralel olarak kullanılsa da Stoacı düşünürler için gösterge kavramı, mantık ve dil alanında gösteren semainon ile gösterilen anlamına gelen semianomenon arasındaki ilişki bağlamında ele alınmıştır (Rifat, 2009:27). Umberto Eco, semeion kavramının Yunanlılar için kendisi dışındaki herhangi bir şeyin yerini alan ve onu imleyen bir araç olarak kullanıldığını belirtir (Eco, 1991:50). Stoacıların, kavramın kullanımını daha genel bir alana taşıdıklarını iddia eden Eco'nun tanımına, Fransızca semiologie kavramının, Yunanca semeion'dan türetildiğini savunan, gösteren farklılıkları arasındaki gösterilen özdeşliğine dikkat çeken Saussure'ün göstergebilim etimolojisinin daha yakın olduğu görülmektedir (Saussure, 1998:46).

17. yüzyılın son çeyreğinde, İngiliz amprist filozof John Locke, göstergebilimi farklı bir bakış açısı ile yorumlamıştır. 1690'da kaleme aldığı An Essay Concerning Human Understanding (İnsanın Anlama Yetisi Üzerine Bir Deneme) isimli eserinde temel bilimleri; Doğa Felsefesi, Etik ve Göstergeler Öğretisi şeklinde üç ana başlıklta inceler. Locke’un konuyu, hem bir başlık olarak ele alması hem de kavramı, semiotike terimi ile incelemesi göstergebilimin adına önemli bir dönüm 
noktasıdır. İngiliz filozof, bu başlık altında belleğin, şeyleri anlamak ya da iletişim kurmak amacı ile kullandığı göstergelerin nitel anlamda analizi olarak görür. Zihni harekete geçiren işaretlerin, anlama yetisine kendisinden başka bir şey sunmadığını ileri süren düşünür, zihnin meşgul olduğu şeyin bir işareti ya da betimi anlama sürecine dahil edilmesi gerektiğini, bu girdinin de ideler olduğunu öne sürer (Locke, 1999:482-483). Sözcüklerin anlamı olarak gördüğü ideleri, zihnin dolaysız nesneleri olarak tanımlar ve insanın dili kullanma becerisinin sesleri, idelerin göstergesi yapabildiği ölçüde mümkün olduğunu savunur (Taylan, 2008:30).

Günümüz, modern göstergebiliminin temellerinin ise 19 ve 20. yüzyıllarda, dilbilim, yapısalcılık ve göstergebilim alanlarında önemli bir yere sahip olan İsviçreli bilim insanı Ferdinand de Saussure ve pragmatizm akımının isim babası olarak kabul edilen Amerikalı filozof Charles Sanders Peirce tarafından atılmıştır.

Göstergenin nedensizliği ilkesi Saussure'ün gösterge bilime yaptığı en büyük katkı olarak kabul edilmektedir. Gösteren ile gösterge arasındaki bağın birbirinden bağımsız oluşu, dilsel anlamda göstergelerin nedensizilğine sebep olmaktadır. Göstergebilimin bu iki temel bileşeni arasındaki nedensizliğe rağmen süregelen iletişim doğal olmayıp bireysel ve toplumsal uzlaşılar sayesinde kendini gerçekleştirebilmektedir (Rifat, 2009:17). Dil öğelerini çözümleyerek elde ettiğimiz dizgelerin, tek başına anlamlanabilirlikten uzak olmaları ve ancak karşılıklı ilişkiler içinde anlam ifade edebilme durumlarını, satranç oyunundaki herbir taşın, ancak diğer taş ile olan ilişkisiyle anlamlı bir hale gelebilmesi anolojisi ile açıklar (Saussure, 1998:119-155). Yapısalcı yaklaşımın önemli isimlerinden biri olan Saussure, dili anlamlı kılan yapının karşıtıklarla örülü olduğunu savunur. Dildeki herbir göstergeyi gösterge yapan şeyin, onu bir diğerinden ayırt edebilmemizi sağlayan değişkenden başka birşey olmadığını ileri süren düşünür, dili bir töz olmanın dışında onu biçim olarak tanımlar (Saussure, 1998:180).

Gösterilen ile gösteren arasındaki ilişkiyi, zıtlıklar ve farklııklar şeklinde, alışılmışın dışında bir gözle yorumlayan Saussure, bu dengesiz gibi görünen işleyişi, sosyokültürel uzlaşıya bağlayarak aslında göstergebilimin ilgi alanını genişletmiştir. Saussere'ün sözel ve yazınsal iletişim, dilin yapısındaki nedensizlik ve karşıtlık yaklaşımları, kültür ve birey arasında iletişim gereken diğer alanlara da sıçramıştır. Bu bakış açısı sayesinde bireyin, kültürel kodlarla inşa ettiği görsel iletişim, tasarım, sanat vb. alanlar da göstergebilimin menziline girmiştir. 
Modern göstergebilimin kurucularından ve günümüzdeki karşılığı ile göstergebilimin bağımsız bir bilim dalına dönüşmesini sağlayan isim ise Charles Sanders Peirce'dır. Bu araştımadaki örnek çalışma, Peirce'ın oluşturduğu terminoloji ve çözümsel algoritma üzerinden kurgulanacaktır. Felsefeyi daha çok pragmatik bağlamda yorumlayan düşünürün bu yaklaşımı, kendisini göstergebilimi ele alışında da göstermektedir.

Bilgiyi ampirik temellere dayandıran Peirce, herhangi bir şey hakkında bilgi sahibiysek bunun o şeyin hissedilebilir etkilerinden kaynaklandığını vurgular. Bu doğrusal düşünce biçimi, göstergebilimi mantıkla özdeşleştirmesinde izlenmekle beraber Semiotic adını verdiği göstergeler öğretisini, kabaca; 1. Salt Dilbilgisi, 2. Mantık ve 3. Salt Sözbilim olarak üçe ayırmasında da kendini gösterir (Rifat, 2009:86). Göstergelerle önermeler arasındaki bağı inceleyen Amerikalı bilim insanı, önermelerin anlamlarını doğruluk değerleri ile belirlenmesi ön koşulunda bulur. Bahsi geçen doğruluğun sadece dilin biçimsel yapısında değil, dilin dışındaki etkenlerde de aranması gerekir. Günlük hayatlarımızdaki düşünce ve işaretlerin, hayatın kendisi ile paralellik göstermesi gerekliliği bu pragmatist bakış açısının bir yansımasıdır. Peirce bu ilişkiyi “Düşünce-işareti düşünüldüğü anlamda nesnesini ifade eder; bu da şu demektir: Bu anlam, düşüncedeki bilincin şimdiki nesnesidir, ya da diğer bir deyişle, düşüncenin kendisidir ya da en azından onun işareti olduğu sonraki düşüncede, düşüncenin ne olarak düşünüldüğüdür" şeklinde özetler. Bu bağlamda idrak edilemeyen düşüncenin varlığının mümkün olmadığı gibi zihni idrake götüren şeyin de işaretler olduğu sonucuna gider (Peirce, 2004:103-126). İşaretler ve göstergelerle günlük yaşantılarımızda geliştirdiğimiz ilişkinin bilgi alışverişinin ötesinde bir düzeyde ve düşünüldüğünden daha katmanlı bir yapıda olduğu rahatlıkla söylenebilir. Bu veri iletişiminin bizleri, bir şekilde anlam yüklediğimiz dış dünya ile ilgili bilgilerin yorumlanması ve eyleme geçme noktalarında, farkında olduğumuz veya olamadağımı aksiyonları almamızda önemli rol oynamaktadır.

Peirce'ın ve göstergebilimsel anlamda kırılma noktası yaratan ve bu araştırmaya konu olan yaklaşımı ise geliştirdiği üçlü göstergeler kuramları arasından, nesneleri açısından bağıntı, benzerlik veya saymacalık içermelerine göre; görüntüsel gösterge, belirti ve simge olarak ayırıp tanımladığı dizilimdir (Vardar, 2001:86). Bu kavramlar görsel çözümlemenin, imge ve izleyen arasındaki ilişkinin yorumlanabilmesi anlamında önemlidir. 
Görüntüsel gösterge; sadece sahip olduğu özelliklerden dolayı kendisini anlamlı kılan, belirttiği şeyi doğrudan temsil eden yani herhangi bir yorumlayana ihtiyacı olmadan kendini ifade eden göstergelerdir. Benzetge olarak da adlandırılan ve ancak nesnesi ortadan kalktığı zaman iletişim gücünü kaybeden kavrama, fotoğraflar, haritalar ve diyagramlar örnek olarak gösterilebilir (Görsel 1) (Erkman, 1987:47; Sayın, 2007:1017; Türer, 2003:157).
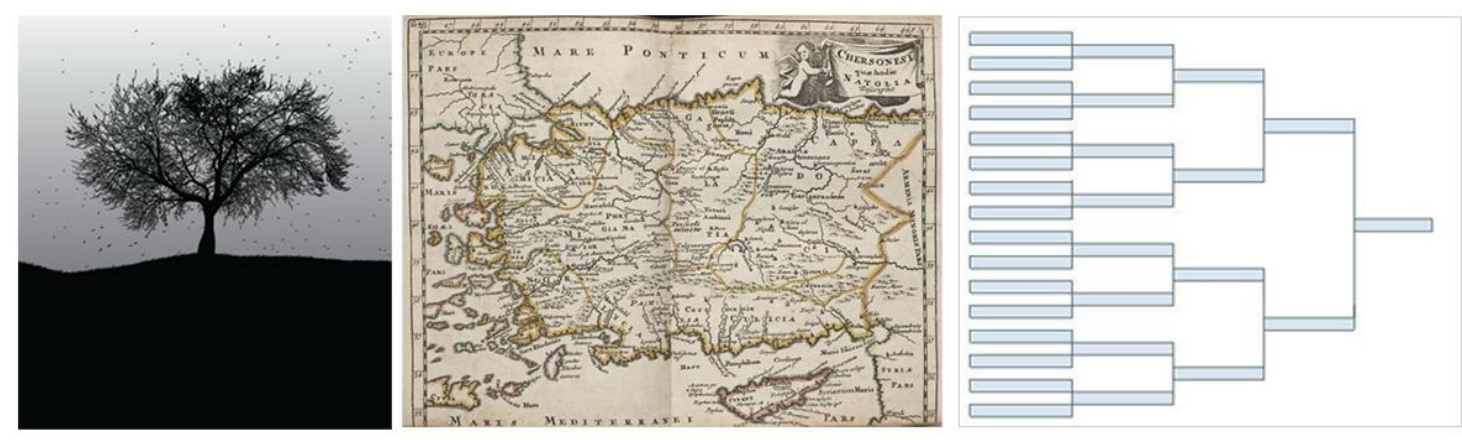

Görsel 1. Fotoğraf, Harita ve Diayagram Örneği.

Belirti ise varlığı ile dolaylı olarak işaret ettiği anlatıya götürerek ilişki kurmamızı sağlayan verilerdir. Index ya da belirtge olarak da tanımlanan kavramın nesnesi ortadan kalktığında gösterge olabilme yetisini de kaybeder. Belirtisel göstergeler, yansıtmak istedikleri göstergelerle tamamen benzememekle beraber ilgisiz oldukları da söylenemez (Sayın, 2007:1017). Bir insanın ten renginin kızarmış olmasının, mental ya da alerjik bir tepkiyi belirtmesi ya da yangın, fırtına vb. doğa olaylarının izleyenle kurduğu sebep sonuç ilişkisi de belirtge kavramına örnek olarak gösterilebilir.

Simge kavramı ise görüntüsel gösterge ve belirtiden farklı bir iletişim kurma prensibine sahiptir. Symbol olarak da adlandırılan kavram üzerine farklı yorumlar mevcuttur. Peirce'ın ilk tanımı; temsil ettiği özelliği, yorumlayanına bağıı olan göstergeler, ikincisi; genel düşüncelerin ortak paydasındaki nesneyi işaret eden göstergeler şeklindedir. Mehmet Rıfat ise; "yorumlayan olmadığında kendisini gösterge yapan özelliği bulunmayan göstergeler." olarak tanımlar (Rifat, 1992:22). Bu tanımlar incelendiğinde simgelerin yorumlanmasında birey ve bireylerarası uzlaşı faktörünün önemi dikkat çekmektedir. Bu bağlamda düşünüldüğünde ortak uzlaşı üzerinden kurduğumuz görsel ilişkiler ve aracılarını simgeler olarak tanımlamak mümkündür. Harfler, 
kelimeler, cümleler, sayılar, belirttikleri şeyler, görsel anlamda ifade ettikleri şeylerden bağımsız, ortak kabulümüzle anlam bulduklarından simge örneği olarak gösterilebilir.

\section{Hareketli Grafiklerin Görsel Iletişim Tasarımındaki Yeri}

"Her gösterge kendinden önceki ve sonraki ile bağıntısında anlam kazanır" Charles Sanders Peirce (Colebrook, 2013:104). Düz anlam, tipogram, metonimi, benzetme, anoloji, paradigma, metafor vb. (Ambrose, 2013:5) yollara kurguladığımız görsel iletişim tasarımı, teknolojik ve kültürel değişimlerin etkisi ile kendi yöntem ve tekniklerini yeniden tanımlamıştır. Yaşadığımız bu değişim bizlere, hem anlatının içeriğinde hem de iletimi sağlayan medyumlarda, imge tasarımına dair değişen biçemi gözlemleme şansı vermiştir (Burnett, 2012:83). 20. yüzyılın başında tasarım paradigmasına hareket olgusunun eklenmesi, izleyici ile imge arasındaki ilişkiyi sarsarak doğal algılarımızda kırılmalara sebep olmuştur. Belirli bir zaman aralığında, imgelerin hareketlerinin kurgulanıp yönetilmesi eylemi olarak tanımlayabileceğimiz hareketli grafiklerin seyrini, önce sinema ve televizyon daha sonra da günümüz çoklu ortamlarından takip etmek mümkündür.

Marcel Duchamp imzalı Anemic Cinema (Görsel 2), 1920'lerde hareket ile tipografiyi birleştirilmenin izleyici üzerinde ne denli etkili olabileceğini göstermiştir. Anemic Cinema'nın hem alanında öncül hem de ardılları için esin kaynağı olduğu söylenebilir.

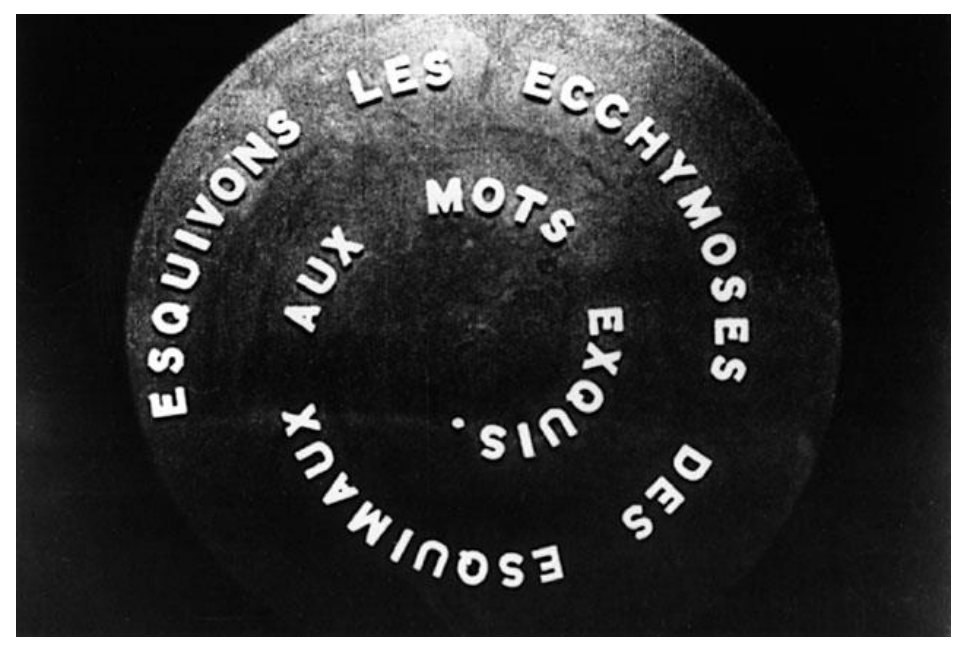

Görsel 2. Anemic Cinema (1920) Filminden Bir Kare. 
1920’ler Filigran kağıtlarla tasarladığı siluetlere hayat veren Lotte Reinger'in Cindirella isimli yapıtına (1920) stok görüntülerle geometrik şekillerin kullanıldığı deneysel, Dadaist bir yapıt olan Hans Richter'ın Filmstudie çalışmasına (1926), Art Deco'nun etkisi ile basit çizgilerle kurgulanan Viking Eggeling'in Symphonie Diagonale (1924) (Görsel 3) adlı eserine tanıklık ederek deneysel hareketli grafikler alanında yükselen bir eğri göstermiştir.
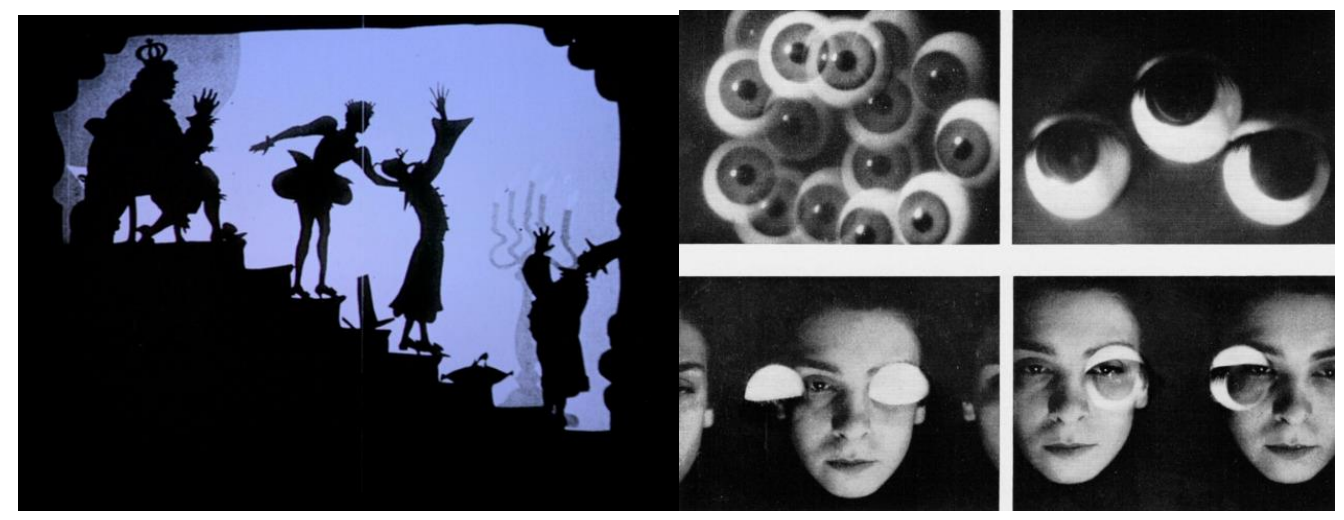

Görsel 3. Cindirella(1920), Filmstudie(1926), Symphonie Diagonale(1924) Filmlerinden Örnek Kareler.

20. yüzyılın ikinci çeyreğinde insanoğlu iletişim biçemimizde kırılma yaratacak yeni bir medyum olan televizyonla tanışmıştır. Haberdar olma niceliğimizde radikal bir değişime önayak olan bu aracın eşzamanlı yayın yapabilme becerisi, yaşadı̆̆ımız dünyanın ölçeğini çok daha küçük bir hale getirmiştir. Televizyon yayını, tasarlanması gereken çok daha fazla hareketli alanlar ortaya çıkarmıştır, bu durum hareketli grafiklere olan ihtiyacı daha da artırmıştır.

BBC televizyonu için tasarladığı logoyu (Görsel 4) mekanik ve hareketli bir düzeneğe çevirip kullanmasıyla Abram Games'in 1953 yılında hareketli logo tasarımının ilk örneğini ortaya koyduğu söylenebilir. Heykeltraş J. F. Johnson ile birlikte tahta, metal ve piyano telleri ile gerçekleştirilen çalışmanın dıştan içe doğru seyreden bir hareket kurgusu vardır (Krasner, 2008; Atiker, 2009). 


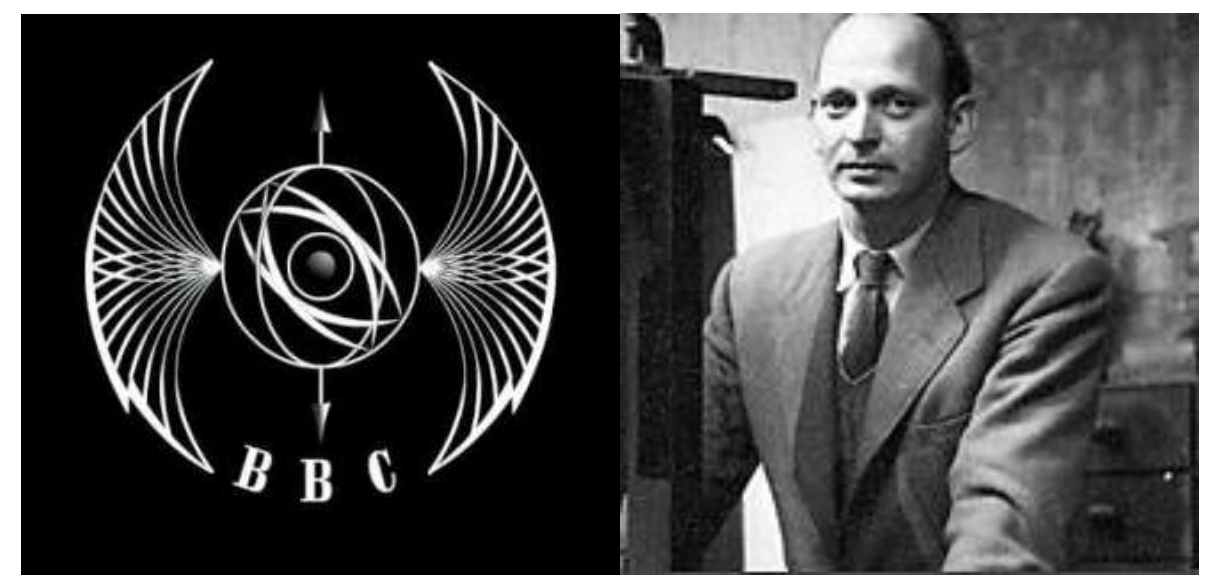

Görsel 4. BBC Televizyonu İçin Tasarlanan Logo ve Tasarımcısı Abram Games.

1950'lerde ise hareketli grafiklere, yükselen sinema sektörü damgasını vurmuştur. Sektörün artan bir ivme ile üretim yapması, sinemaya olan ilgiyi artırmak için tasarlanan jenerik tasarımına olan ihtiyacı da tetikleyerek hareketli grafikler için önemli bir alan haline getirmiştir. Otto Preminger'in yönettiği The Man With The Golden Arm (1955) için Saull Bass tarafından tasarlanan jenerik, alanın öncül işlerinden olarak kabul edilirken Maurice Binder Dr. No ile başlayıp Liecence to Kill ile biten 14 filmlik bir jenerik tasarımı serisine imza atarak literatüre giren başka bir hareketli grafik tasarımcısı olmuştur.

20. yüzyıl dijital devrimle beraber hareketin ifade ediliş biçemi ve tasarımı anlamında köklü değişikliklere sahne olmuştur. Değişen teknoloji, daha önce görülmemiş imge ve form yaratma imkânının tasarımcıların önüne sermiştir (Meggs, 1992:469). Bu yeni imkânlar Greenberg kardeşler için bir ilke imza atma olanağı sunmuştur. Richard Alan Greenberg ve kardeşi Robert Greenberg 1977 yılında ilk hareketli grafik stüdyosunu kurarak aralarında Flash Gordon, Flying, Family Business, Superman gibi filmlerin bulunduğu bir dizi film için jenerik tasarımları yapmışlardır. Bilgisayar ortamında tasarladıkları 3 boyutlu tipografiyi film jeneriklerine taşımaları, hareketli grafik tasarımına kattıkları diğer bir ilk adım olarak kabul edilmektedir (Krasner, 2013:22).

21. yy. ile beraber jenerik tasarımının beraberinde akıllı telefon ve uygulama arayüzleri, medikal görselleştirmeler, bilgilendirme animasyonları vb. birçok alan hareketli grafik tasarımının 
uzmanlık konusu haline gelmiştir. Görsel iletişim tasarımının bu yeni dalı konuda uzman eğitim kurumları ve eğitmen açığını da beraberinde getirmiştir.

Günümüzde kendini her gün yenileyen yazılım mimarileri ve görüntüleme teknolojileri, teknoloji ve tasarım arasındaki ilişkinin baştan yazıımasına sebep olmaktadır. Bu yeni dilin içinde hareketli grafiklerin ve tasarımının yüksek bir öneme sahip olduğu bir açıktır.

\section{Apple Şirketinin Kurumsal Kimliği ve Tasarım Tavrı}

1976 yılında Kaliforniya eyaletinin San Francisco şehrinde Steve Jobs, Ronald Wayne ve Steve Wozniak tarafından Apple Computer Inc. adıyla kurulan teknoloji üreticisi kuruluş, kısa sürede alanındaki rakiplerinden pozitif anlamda ayrılmıştır. Bilgisayar ve işletim sistemi üretimi ile başladığı yola, geliştirdiği akıllı teknolojik ürünler yelpazesiyle alanında öncü bir noktaya yükselmiştir (https://tr.wikipedia.org/wiki/Apple). Teknolojik anlamda geliştirdiği, zamanın sınırlarını zorlayan yenilikçi yaklaşımını, şirketin endüstriyel ve görsel iletişim tasarımı birimlerinde de benimseyerek kurumsal anlamda bir bütünlüğe sahip olduğu gözlemlenmektedir (Görsel 5). Kurumsal kimliğinden yazılım arayüz tasarımlarına kadar iletişimini minimal bir dille inşa eden şirketin, kulvarındaki diğer üreticiler için de ilham kaynağı olduğu söylenebilir.
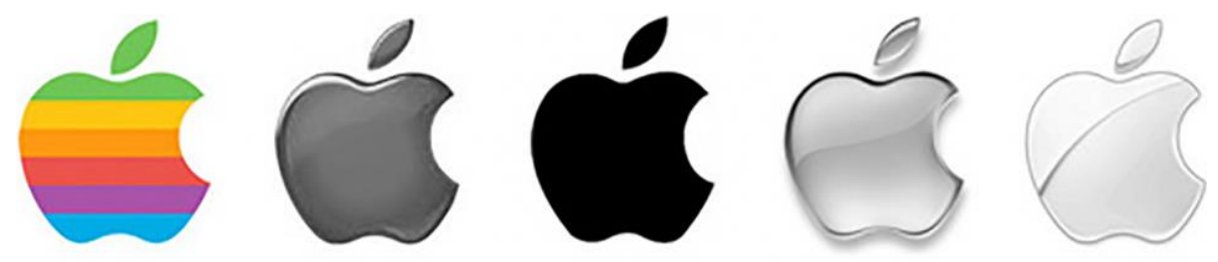

1977

ROB JANOFF

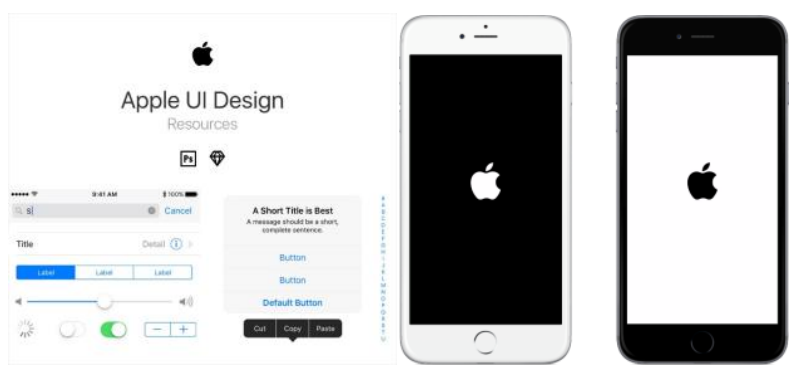

Görsel 5. Apple Şirketinin Logo ve Arayüz Tasarımlarından Örnekler. 


\section{Apple İçin Tasarlanan Hareketli Grafik Çalışması; Intention Örneğinin Hareketli Grafik Tasarımı Anlamında İncelenmesi}

Şirketin 2013 yılında duyurduğu üretim ve tasarım manifestosu için yayımladığı hareketli grafik çalışması, bu araştırmanın göstergebilimsel anlamda konusu olmuştur. Hiçbir ürünün ya da ürünü işaret eden bir göstergenin kullanılmadığı çalışma, alışılagelmiş manifesto ve tanıtım dillerinden farklı bir noktadır. TBWA \Media Arts Lab tarafından üretilen çalışma ilk kez "World Developer Conference" etkinliğinde gösterilmiştir. İngilizce ismi Intention; niyet, maksat, amaç anlamları taşıyan çalışma (https://dictionary.cambridge.org/tr) Apple tasarımlarının “Design by Apple in California" (Apple tarafından Kaliforniya'da tasarlandı) damgasını alabilmesi için neler gerektiği sorusunun cevabı niteliğindedir (https://www.bandt.com.au/Apple-s-designmanifesto-Intention/).

91 saniye uzunluğundaki hareketli grafik çalışması siyah beyazdır. Illetiler, siyah arka plan üzerine beyaz, beyaz arka plan üzerine siyah şeklinde iki farklı sahne üzerinde kurgulanmıştır. Yatay bir kompozisyon kullanılan akışta daire, çember, kare, beşgen, altıgen ve çizgi gibi temel geometrik şekiller kullanılmıştır. Tipografik göstergelerden de yararlanılan çalışma için sözsüz bir müzik tercih edilmiştir.

Anlatının başkahramanı, izleğin seyrine göre farklı şekillere ve zıt renge dönüşen bir dairedir. Hikâyeye yön veren daire, diğer tasarım elemanları ile girdiği ilişkinin şekliyle mesajı anlamlı kılmamızı sağlar. İzleğin genelini 3 parçaya ayırıp incelemek mümkündür; hikâyenin geçeceği evrenin yaratıldığı ve probleminin izleyiciye iletildiği, 14. saniyeye olan birinci kısım (Görsel 6a), ilk bölümde yaratılan soru işaretleri ve gerilimin işlendiği, 88. saniyeye kadar olan ikinci kısım (Görsel 6b) ve merakın sonuçlandırılıp anlatının tamamlandığı üçüncü kısım (Görsel 6c). 
SDÜ ART-E

Güzel Sanatlar Fakültesi Sanat Dergisi

Aralık'21 Cilt:14 Sayı:28

ISSN 1308-2698

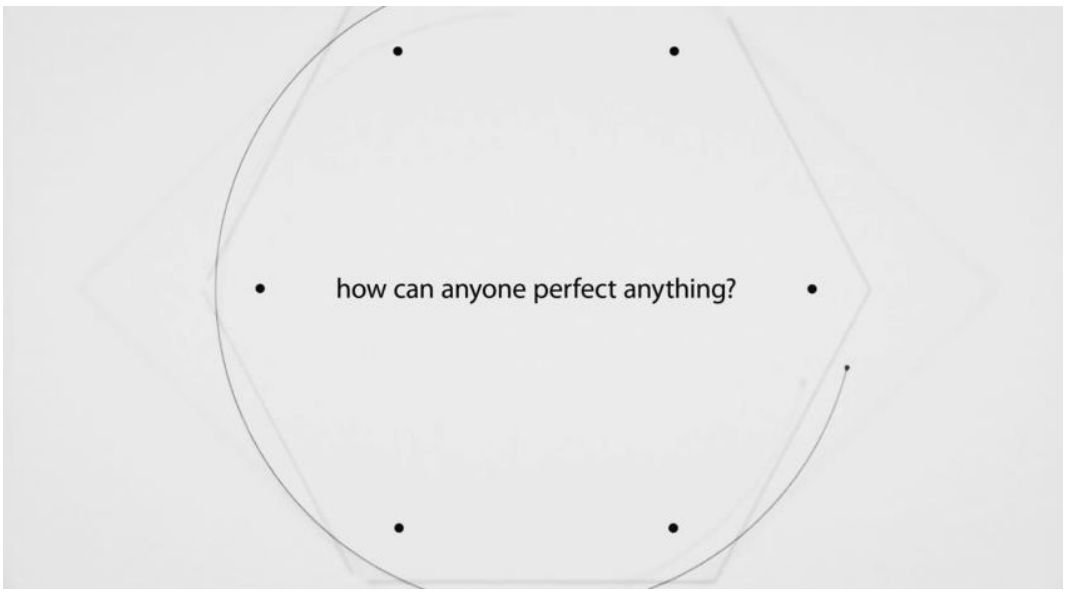

Görsel 6a. Apple Şirketi İçin Tasarlanan Intention Filminden Ekran Görüntüsü

only then do we sign our work.

Görsel 6b. Apple Şirketi İçin Tasarlanan Intention Filminden Ekran Görüntüsü 
Görsel 6c. Apple Şirketi İçin Tasarlanan Intention Filminden Ekran Görüntüsü.

Giriş sahnesinde boş beyaz bir ekran ardından ilk planla karşılaşmaktayız (Görsel 7). "if everyone" (eğer herkes) tipografisi ve birleştirildiğinde kare şeklini oluşturabilecek konumda 4 siyah daire görünmektedir. Bu sahne görsel evrenin oluşturulması, kullanılan görsel elemanlar ile onlara yüklenen anlamların izleyiciye iletilmesi açısından önemlidir. "Everyone"(herkes) tipografisinin görünmesi ile eş zamanlı hareket eden siyah daireler, bu ikili arasında anlam birliği sağlamaktadır.

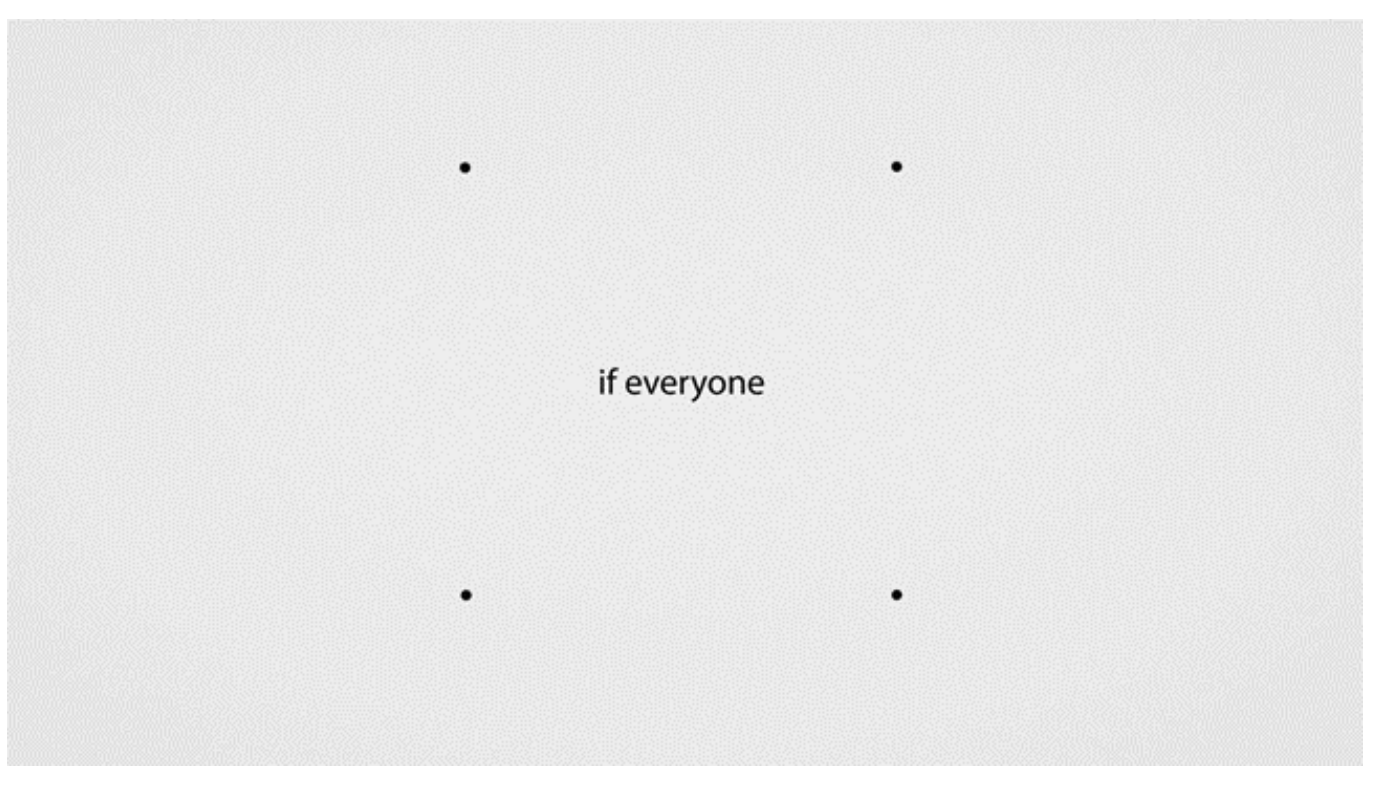

Görsel 7. Apple Şirketi İçin Tasarlanan Intention Filminden Ekran Görüntüsü. 
İzleyiciye aktarılan daire ve birey eşleşmesinden sonra verilmek istenen tüm mesajlar, ana karakterimiz olan siyah daire ve ona eşlik eden temel geometrik şekiller ve tipografi ile iletilmektedir. Süreklilik, tekrar, doğrusallık ve döngüsellik gibi anlamlar taşıyan çember ve daire formu, izleğin akışına göre farklı rollerde de kullanılmıştır. 55. Saniyede, imlada, tamamlanmamış durumlar için kullanılan üç noktanın sonuncusu olarak zamansal bir akışı ifade ederken (Görsel 8a), 61. Saniyede, hikâyede geçen "there are a thousand no's"(bin hayır var) anlatısındaki her bir hayırı imlemek için kullanılmıştır (Görsel 8b). Çalışmanın sonuç bölümünde (70. Saniyede) ise manifestonun kimin tarafından söylendiğine ve kurumsal yapıya işaret eden tipografinin arkasında kullanılarak bu iki veriyi birleştirme görevini üstlenmiştir (Görsel 8c).

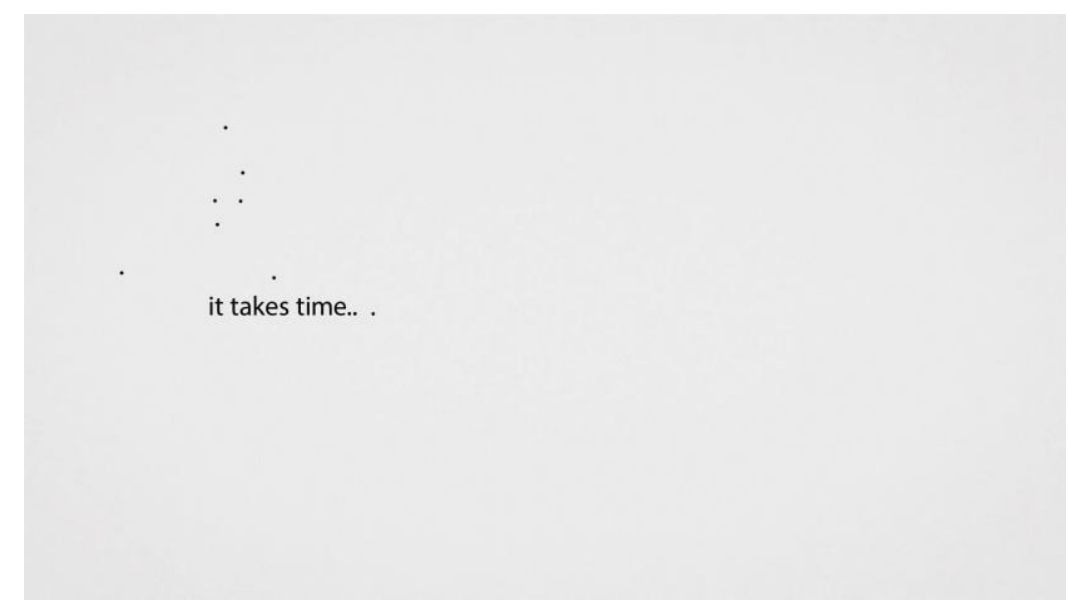

Görsel 8a. Apple Şirketi İçin Tasarlanan Intention Filminden Ekran Görüntüsü.

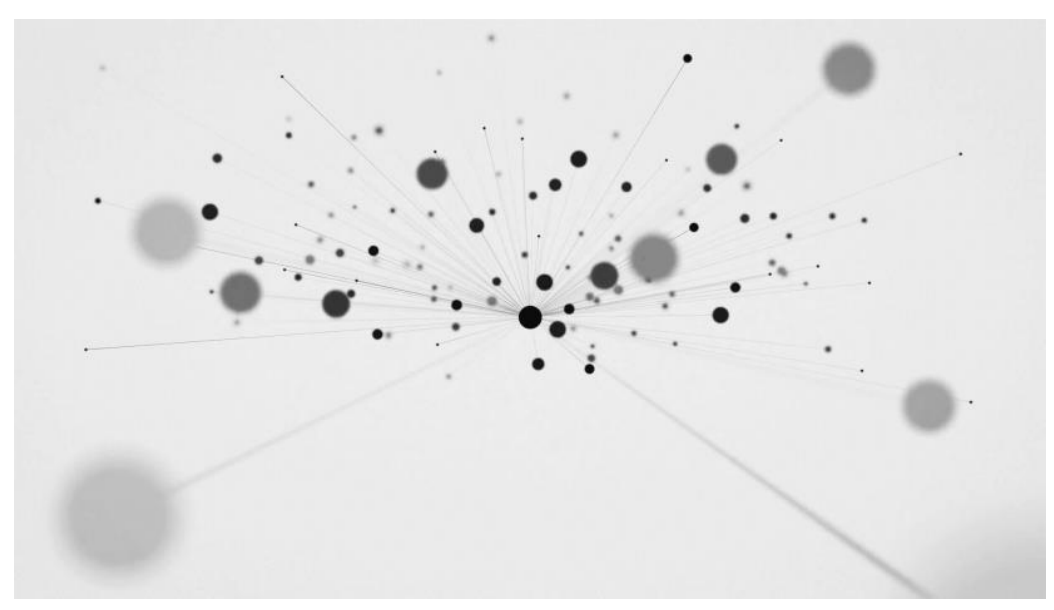

Görsel 8b. Apple Şirketi İçin Tasarlanan Intention Filminden Ekran Görüntüsü. 


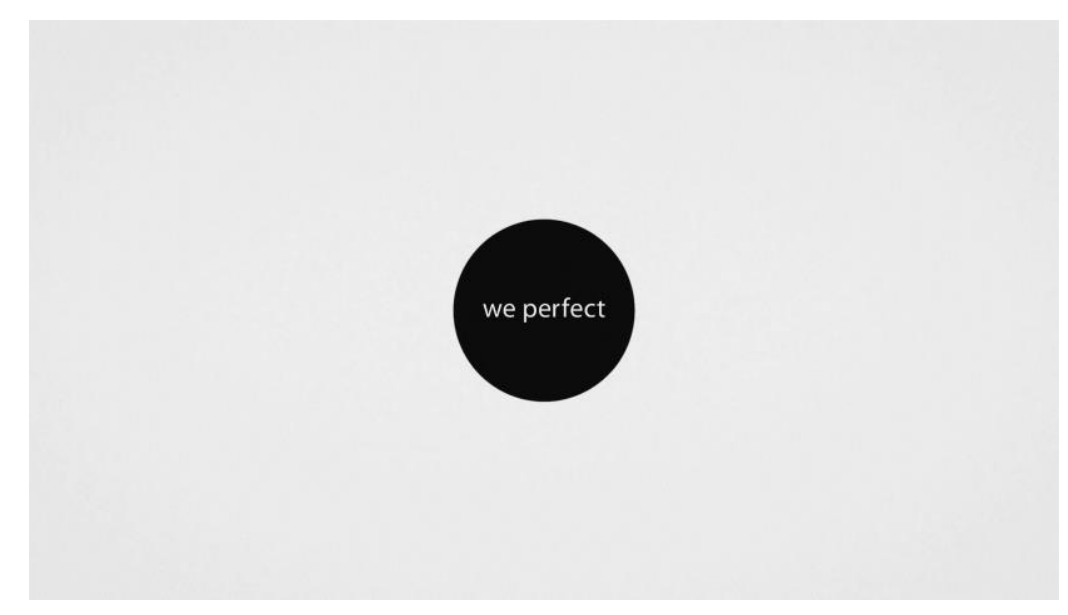

Görsel 8c. Apple Şirketi İçin Tasarlanan Intention Filminden Ekran Görüntüsü.

Hareketli grafik tasarımı anlamında minimal ve akıcı bir üslupta sonuçlandırılan çalışmanın, iletmek istediği mesajı merkeze alarak süslemeden uzak, sade bir dil kullanması sebebi ile izleyen ve mesaj arasında başarılı bir iletişim kurduğu söylenebilir.

\section{Apple İ̧̧in Tasarlanan Hareketli Grafik Çalışması; Intention Örneğinin Göstergebilimsel Çözümlenmesi}

Intention örneği Peirce'in göstergebilimsel yöntemi ile analiz edildiğinde, ilk aşamada görüntüsel göstergelerin incelenmesi gerekmektedir. Çalışmanın başrolünü çember ve daire göstergesi üstlenmektedir. Devingenlik, tekrar, süreklilik, sonsuzluk, tekillik ve bütünlük gibi kavramlarla eşleştirilen göstergeler (Görsel 9), anlatının yalın bir dille ifade edilmesini sağlarken hareketli grafik çalışması olmasından dolayı sahnelerin bağlamlarına göre imledikleri kavramlarda da farklılıklar meydana getirmektedirler. Bu görüntüsel göstergelerin, verilmek istenen mesajın kendisi için hizmet etmekle beraber esas görevinin mesajı verenin niteliklerini imgelemek olduğu da okunur. Benzerlerinin hem endüstriyel hem de grafik tasarım anlamında kullandıkları şaşalı dilin aksine hiçbir renk kullanmadan işlenen daire ve çember görüntüsel göstergeleri ile hikâyenin anlatılması, mesajı veren tarafın gücünü rakiplerine görsel bir manifesto ile gösterme arzusu olarak da yorumlanabilir. 


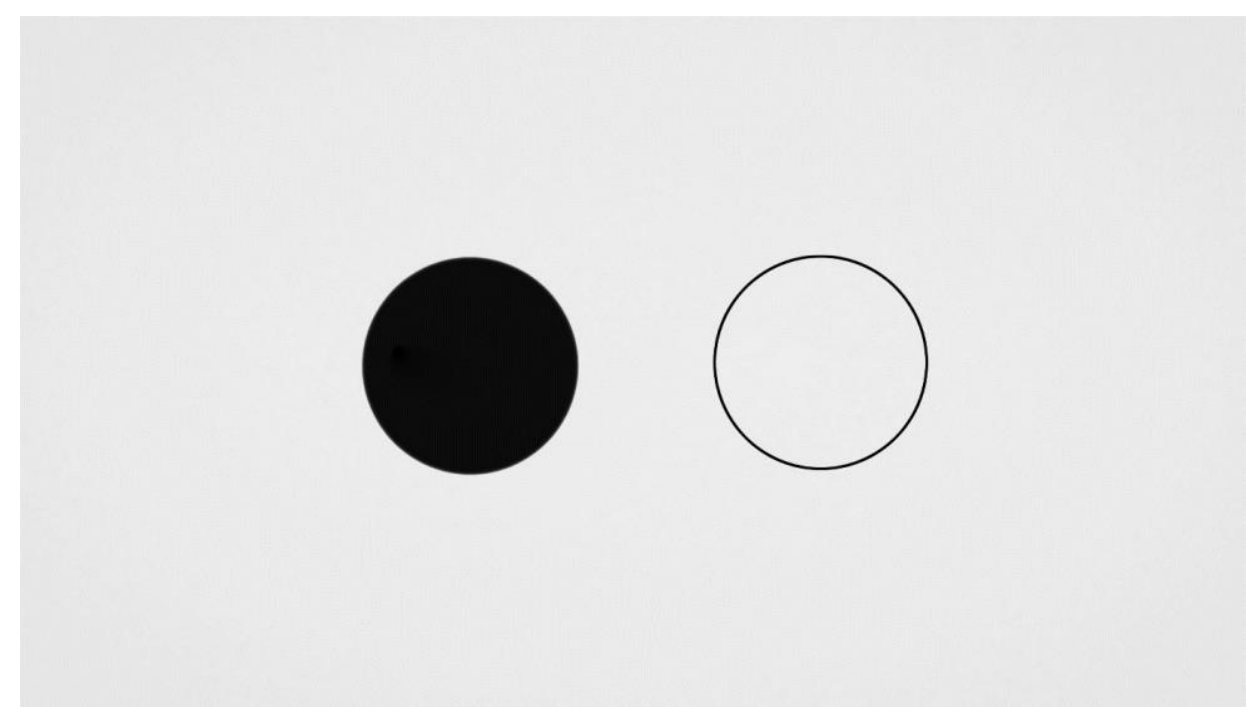

Görsel 9. Apple Şirketi İçin Tasarlanan Intention Filminden Ekran Görüntüsü.

Çalışmadaki göstergeler Peirce'ın belirti tanımı açısından incelendiğinde birçok örnek görmek mümkündür, bu sebeple etkisinin güçlü olduğu düşünülen iki örnek sahne üzerinden analiz yapılmıştır. Yansıtmak istedikleri göstergelere ne tamamen benzeyen ne de ilgisiz olan belirti kavramının ilk örneğini 10. saniyede görmekteyiz. Soru işaretlerinin yaratıldığı bölüm olarak tanımladığımız bu sekansta (Görsel 10) giriş sahnesi ile izleyiciye verilen daire=birey denklemi, iletilmek istenen mesaj doğrultusunda hikayeleştirilerek işlenmektedir. Sahnedeki yarım kalan cümlenin tamamı "if everyone is busy making everything" (herkes herşeyi yapmakla meşgulse) şeklindedir. Bu veri ile sahnede, çalışma, toplantı vb. masa şekillerine benzetilen çember, kare, beşgen ve altıgen gibi temel geometrik formların etrafında birey tanımlı siyah daireler, arkasında çizgi bırakarak aceleci bir tavırla hareket etmektedirler. Bu göstergeler bütünü ile betimlenen yoğun ofis ortamında, bireylerin arkasında bıraktıkları temel geometrik şekillerin zamanla yok olduğu görülmektedir. Bu sekanstaki göstergeler, noktaların hareket hızları ve kaybolan çizgilerle beraber yorumlandığında acele ile yapılan birçok proje, iş vb. etkinliğin aslında istenilen noktaya bir türlü gelemeyen eylemler döngüsünün görsel belirtileri olarak okunabilir. 


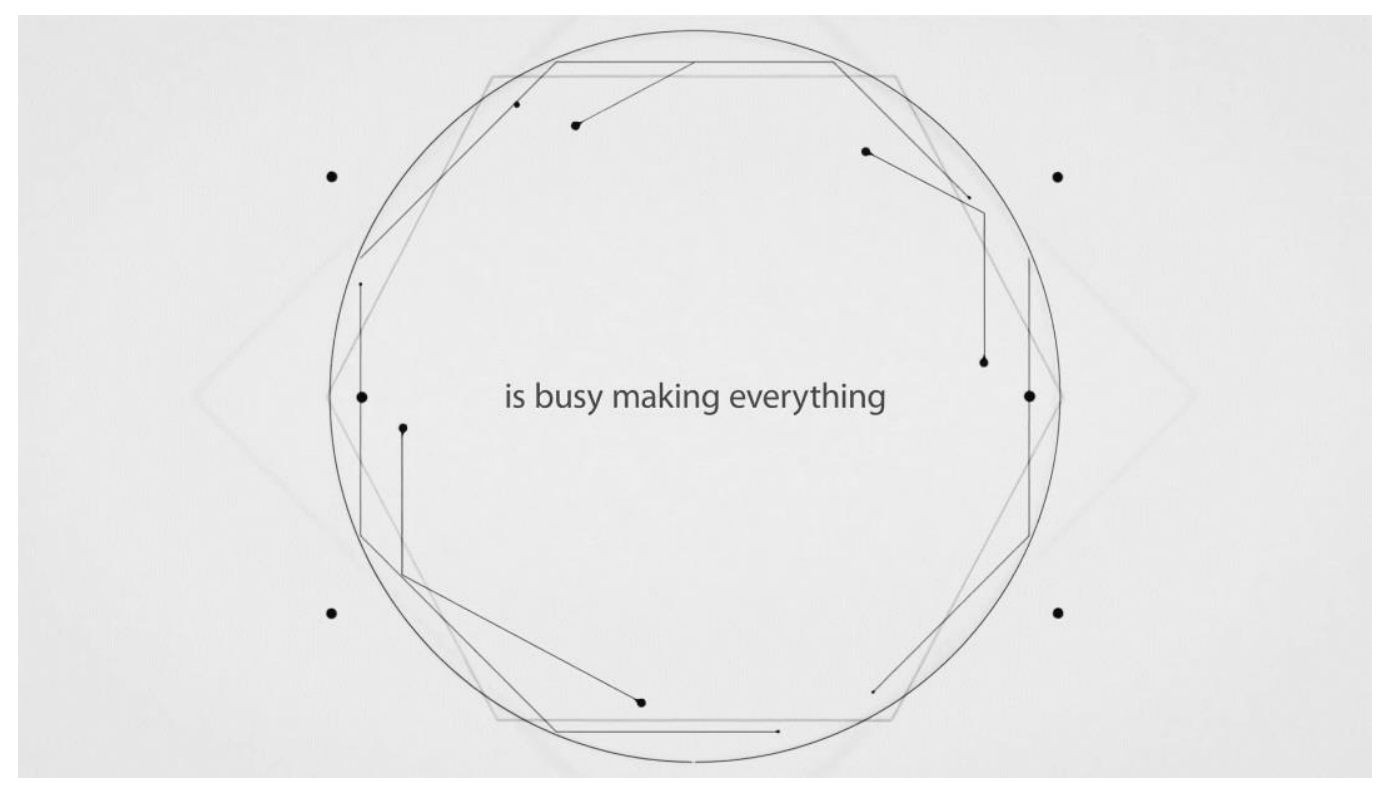

Görsel 10. Apple Şirketi İçin Tasarlanan Intention Filminden Ekran Görüntüsü.

Bir diğer belirti örneğini ise 71. Saniyede görmekteyiz. Ulaşılmak istenen tasarım noktasına giden sürecin anlatıldığı bu bölümde, bir tasarım fikrinin hangi filtrelerden geçtiği görselleştirilmiştir. Çalışılmaya, üzerinde düşünülmeye değer her fikri kolaylaştırmak (sade bir dile dökmek anlamında) ve kusursuza ulaştırmak için sürece yeniden başlanılması gerektiği iletilmektedir. Bu sahnenin göstergebilimsel anlamda gerilim noktası ise "we start over"(yeniden başlarız) karesidir( Görsel 11a). Yeniden başlama eylemi iki farklı şekilde verilmektedir. İlk iletide (Görsel 11a) gösterge, kültürel kodlar üzerinden anlaşı sağladığımız tipografik bir düzenleme ile izleyiciye direkt iletilmiştir. İkinci aşamada ise mesaj, belirti tanımının prensiplerinden faydalanarak ifade edilmiştir. Yeniden başlama eylemi, "yeniden başlarız" tipografik göstergesindeki, harflerin deforme edilerek eksiltilmesi ile gerçekleştirilmiştir (Görsel 11b). Bu noktada, yazılan bir yazının silinmesinden kalan izler görmekteyiz. Gördüğümüz silinme izleri, mevcut süreçten vazgeçmek ya da tekrarlanmak üzere yapılmış bir hamlenin belirtisi olarak okunmaktadır. Bu örneğin içindeki, başa dönüşü imleyen diğer bir belirti ise hareket bileşeninden faydalanılarak uygulanmıştır. Soldan sağa yazılan tipografik göstergeyi sağdan sola silerek hem zamansal hem de biçimsel anlamda yeni bir başlangıç vurgulanmaktadır. 


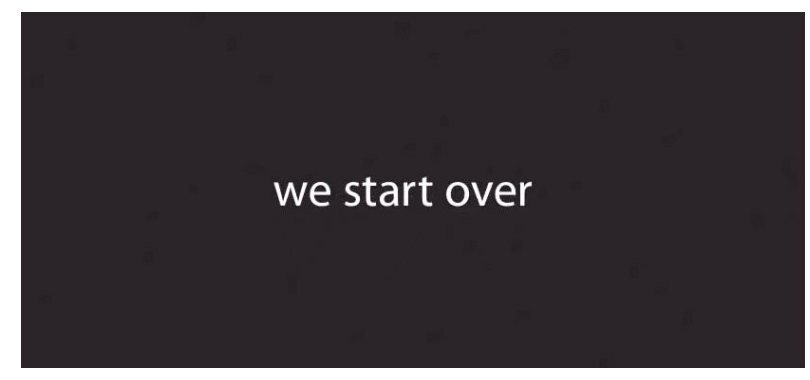

Görsel 11a. Apple Şirketi İçin Tasarlanan Intention Filminden Ekran Görüntüsü. b (altta), Apple Şirketi İçin Tasarlanan Intention Filminden Ekran Görüntüsü

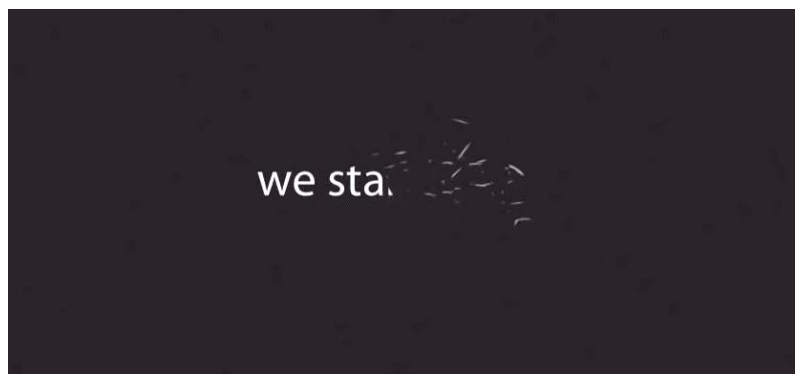

Görsel 11b. Apple Şirketi İçin Tasarlanan Intention Filminden Ekran Görüntüsü

Intention örneği, belirtisel göstergelerde olduğu gibi simgsesel göstergeler açısından da zengin bir içeriğe sahiptir. Simge kavramı temel seviyede, kültürel kodlar üzerinden toplumsal uzlaşı sağladığımız gösterge ve gösterilen ilişkileri olarak tanımlanmaktadır. İlk bakışta, kullanılan simgelerin, manifestonun daha kapsayıcı olabilmesi adına, birçok kültürde karşılıkları birbirine yakın olan kavramlardan seçildiği gözlemlenmektedir. Seçilen simgeler, "surprise" (sürpriz) (Görsel 12a) ve "love"(aşk) (Görsel 12b) şeklindedir. Peirce'ın simge tanımı üzerinden analiz edildiğinde bu üç kavramın da izleyici ile benzer bir iletişim kurma yoluna gittiği anlaşılmaktadır. Hareketli grafikler biçemin avantajları ile güçlendirilen ifadelerin ilki sürpriz kavramıdır. Beklenmedik bir zamanda gerçekleşen beklenmedik bir durum ya da olay şeklinde tanımlayabileceğimiz sürpriz kelimesi, izleğin ana karakteri olan siyah karenin bir anda patlaması ve daha küçük siyah dairelerin saçılması ile görselleştirilmiştir. Sürpriz doğum günü vb. etkinliklerde yaşanan ani aksiyonların ortaklığından yola çıkan gösterge, bu payda ile sürpriz kavramının simgesi haline gelmektedir. İkinci örnek aşk kavramıdır. Üzerinde görsel, yazınsal, işitsel birçok tanım ve yorumun bulunduğu kavram, intention örneğinde kesişim durumu üzerinden işlenmiştir. Giriş sahnesinde birey olarak kodladığımız siyah daireler birbrilerine yaklaşarak iç içe geçmektedirler. Yine toplumsal uzlaşı ile inşaa ettiğimiz tipografik göstergeler 


\section{SDÜ ART-E}

Güzel Sanatlar Fakültesi Sanat Dergisi

Aralık'21 Cilt:14 Sayı:28 ISSN 1308-2698

olmadan düşünüldüğünde, matematik dersindeki kümeler konusundan bir ifade olarak yorumlayabileceğimiz görsel, kesişmek, paylaşmak, beraber farklı bir şeye dönüşmek gibi alt anlamların çalıştırılıp hikâye sürecinin başarılı kodlanması ile aşk kavramının simgesi haline dönüşmüştür.

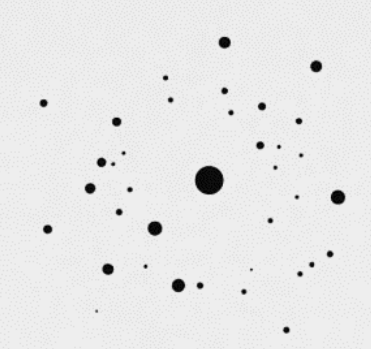

surprise

Görsel 12a. Apple Şirketi İçin Tasarlanan Intention Filminden Ekran Görüntüsü

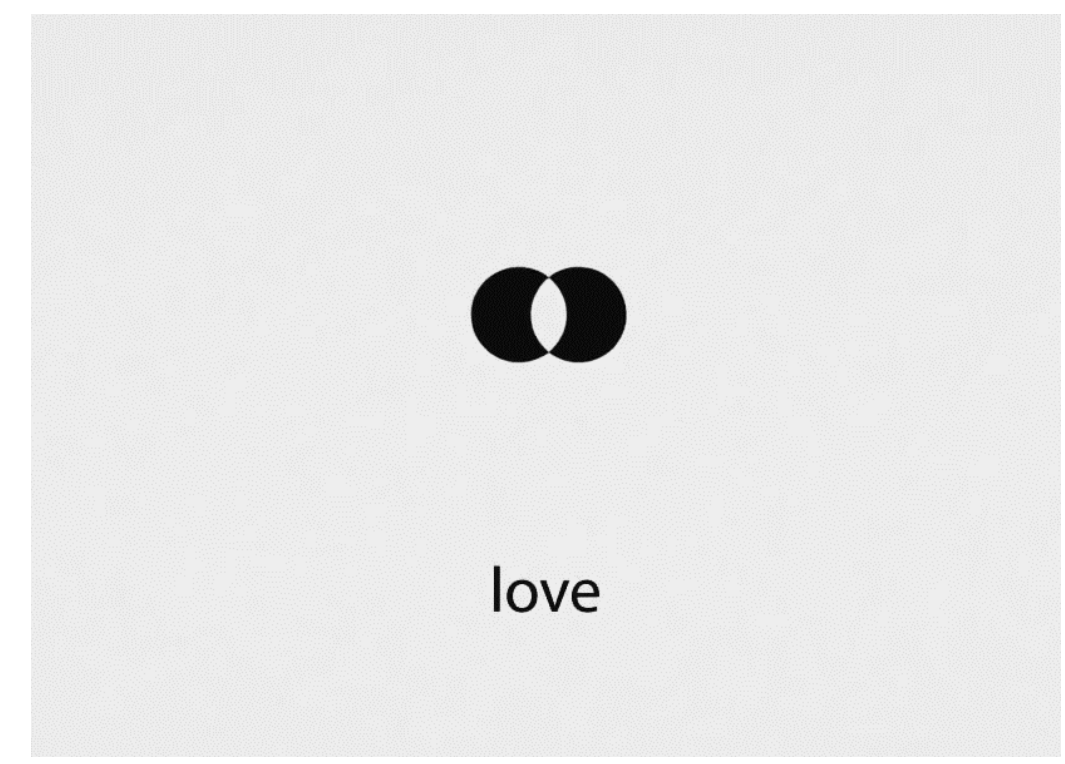

Görsel 12b. Apple Şirketi İçin Tasarlanan Intention Filminden Ekran Görüntüsü 


\section{Sonuç}

Hem endüstriyel hem de görsel iletişim tasarımı anlamında özgün bir dile sahip olan Apple şirketinin tasarım manifestosu göstergebilimsel olarak incelenmiştir. Temel geometrik şekillerle kurgulanan hareketli grafik çalışmasının göstergebilimsel anlamda zengin bir içeriğe sahip olduğu görülmüştür. Sürecin, durağan grafik tasarım ürünlerinin göstergebilimsel analizindeki yöntemlerle kesiştiği ve ayrıştığı noktalar olduğu saptanmıştır. Statik imge analizinde, çıkarımların o kare üzerinden sonuçlandırılması durumunun aksine gösterge tanımlarının sahnenin bağlamına ve akışına göre anlam kaymalarına uğradığı tespit edilmiştir. Bu durum, göstergebilimsel analizi daha güç hale getirmekle beraber imgelerin değişen görevleri konusunda araştırmacıyı daha yüksek bir farkındalık seviyesine doğru zorlamaktadır. Seçilen örnek, temel geometrik şekillerle dahi plan, sekans, sahne, ses, kompozisyon ve hareket gibi bileşenlerin yönetimi ile göstergelerin anlamlarının ne kadar hızlı değişebileceğini göstermiştir. Hareketli grafik tasarımının günümüz iletişim araçlarındaki yoğun kullanımı ve tüketicisinin ilgili izleğe ayırdığı zaman dilimi düşünüldüğünde, Peirce'ın imge ile izleyici arasında kurduğu iletişim köprüsündeki görsel katmanların, farkında olmasak da son derece hızla anlamlandırılıp yorumlandığı görülmüştür.

Sonuç olarak, analizi yapılan bu hareketli grafik çalışmasındaki göstergelerin, biçimsel deformasyonlara uğramadan da göstergebilimsel tanımlarının değişebildiği gözlemlenmiştir. Bu anlam kaymalarının, tasarımcı kontrolünde baştan sona bir bütünlük göstermesi, seyrin akıcılığını artıran bir bileşen olarak ortaya çıkmaktadır. Kompozisyon dengesi ve izlek ritminin anlatıyla uyum içinde seyretmesinin, bağlam üstünde hayati önem taşıyan diğer bir girdi olduğu gözlemlenmiştir 


\section{Kaynakça}

Ambrose, G. (2010). Görsel Grafik Tasarım Sözlüğü, çev. Bilge Barhana, İstanbul: Literatür Yayınları.

Arıkan, A. (2008) Grafik Tasarımda Görsel Algı, İstanbul: Eğitim Kitabevi Yayınları.

Atiker, B. (2009) Hareketli Grafiklerin Evrimi ve Hacettepe Üniversitesi Güzel Sanatlar Fakültesi İçin Bir Uygulama Örneği, Yayımlanmış Doktora Tezi, Ankara: Hacettepe Üniversitesi Güzel Sanatlar Enstitüsü.

Burnet, R., Iso, K., Eduard M. (1993) An Introduction to Husserlian Phenomenology, Evanston, IL: Northwestern University Press.

Colebrook, C. (2013). Gilles Deleuze, çev. C. Soydemir, Ankara: Doğubatı.

Eco, U. (1991) Umberto. Alımlama Göstergebilimi, çev. Sema Rifat, İstanbul: Düzlem Yayınları. Erkman, F. (1987) Göstergebilime Giriş, İstanbul: Alan Yayıncılık.

Locke, J. (1999) Insanın Anlama Yetisi Üzerine Bir Deneme. Çev Meral Delikara Topçu, Ankara: Öteki Yayınevi.

Krasner, J. (2013) Motiongraphic Design. New York/India: Focal Press/ Replika Press.

Meggs, P. (1992) A History of Graphic Design, Newyork: Van Nostrand Reinhold Company.

Peirce, C. (2004) Mantık Üzerine Yazılar, çev. Halit Yıldız, Ankara: Öteki Yayınevi.

Rifat, M. (1992) Göstergebilimin ABCsi, İstanbul: Simavi Yayınları.

Rifat, M. (2009) Dilbilim ve Göstergebilimin Çağdaş Kuramları, İstanbul: Yapı Kredi Yayınları.

Saussure, F. (1998) Genel Dilbilim Dersleri, çev. Berke Vardar, İstanbul: Multılıngual Yabancı Dil Yayınları.

Sayın, Z. (2007) Gösteren-Gösterilen Iliş̧kisi Açısından Grafik Göstergeler ve Göstergeleri Algılayış Farklııkları, "Görünürün Kültürleri”, 8. Uluslararası Görsel Göstergebilim Kongresi, İstanbul.

Taylan, A. (2008) Dile Gelen Felsefe, İstanbul: Yapı Kredi Yayınları.

Türer, C. (2003) Charles Peirce'ün Pragmatik Felsefesi, İstanbul: Üniversite Kitabevi.

Vardar, B. (2001) Dilbilimin Temel Kavram ve Ilkeleri, İstanbul: Multilingual Yayınları. 


\section{Internet Kaynakları}

"apple", https://tr.wikipedia.org/wiki/Apple, Erişim tarihi: 26.02.2021

"dictionary", https://dictionary.cambridge.org/tr, Erişim tarihi: 28.02.2021

"design manifesto of intention", https://www.bandt.com.au/Apple-s-design-manifestoIntention, Erişim tarihi: 21.02.2021

\section{Görsel Kaynaklar}

Görsel 1. https://tr.pinterest.com/pin/766526799049456292/ Erişim tarihi: 10.07.2021.

https://www.mapsof.net/turkey/anatolia-historical-map- Erişim tarihi: 10.07.2021.

https://www.template.net/business/family-tree-templates/family-tree-diagram/ Erişim tarihi: 10.07.2021.

Görsel 2. http://smfafilm.blogspot.com/2012/11/anemic-cinema-marcel-duchamp.html Erişim tarihi:12.07.2021.

Görsel 3. https://drnorth.files.wordpress.com/2009/10/vlcsnap-2009-10-15-20h58m32s88.png, https://66.media.tumblr.com/tumblr_m19pnylo4v1qfg94wo1_1280.jpg, Erişim tarihi: 12.07. 2021.http://anthologyfilmarchives.org/collections/reference-library/stills/1220, Erişim tarihi: 12.07. 2021.

Görsel 4. https://www.bbc.com/historyofthebbc/research/bbc-idents/television-symbol Erişim tarihi: 12.07.2021.

Görsel 5. https://www.artofthetitle.com/studio/r-greenberg-associates-r-ga, Erişim tarihi: 12.07.2021.

https://www.forbes.com, Erişim tarihi: 16.07.2021.

https://freebiesui.com/sketch-freebies/apple-ui-design-resources-for-psd-sketch, Erişim tarihi: 16.07.2021.

https://www.idownloadblog.com/2016/03/24/invertrespring/ Erişim tarihi: 16.07.2021.

Görsel 6a https://vimeo.com/241783590 Erişim tarihi: 21.07.2021.

Görsel 6b https://vimeo.com/241783590 Erişim tarihi: 21.07.2021.

Görsel 6c https://vimeo.com/241783590 Erişim tarihi: 21.07.2021.

Görsel 7. https://vimeo.com/241783590 Erişim tarihi: 21.07.2021. 
Görsel 8a. https://vimeo.com/241783590 Erişim tarihi: 21.07.2021.

Görsel 8b. https://vimeo.com/241783590 Erişim tarihi: 21.07.2021.

Görsel 8c. https://vimeo.com/241783590 Erişim tarihi: 21.07.2021.

Görsel 9. https://vimeo.com/241783590 Erişim tarihi: 21.07.2021.

Görsel 10. https://vimeo.com/241783590 Erişim tarihi: 21.07.2021.

Görsel 11a. https://vimeo.com/241783590 Erişim tarihi: 21.07.2021.

Görsel 11b. https://vimeo.com/241783590 Erişim tarihi: 21.07.2021.

Görsel 12a. https://vimeo.com/241783590 Erişim tarihi: 21.07.2021.

Görsel 12b. https://vimeo.com/241783590 Erişim tarihi: 21.07.2021. 